\title{
ALLELOPATHIC EFFECT OF Dendrocalamus longispathus KURZ AND Schizostachyum dullooa GAMBLE ON MAIZE AND SOYABEAN CROPS
}

\author{
Ng. Polbina Monsang, Paul Lalremsang, Kalidas Upadhyaya*
}

Department of Forestry, School of Earth Sciences and Natural Resources Management Mizoram University, Tanhril Aizawl, Mizoram - 796004, India

Received - September 12, 2019; Revision - November 18, 2019; Accepted - November 29, 2019

Available Online - December 25, 2019

DOI: http://dx.doi.org/10.18006/2019.7(6).536.544

\section{KEYWORDS}

Agricultural food crops

Allelopathic effect

Bamboos

Biomass

Inhibitory effect

\begin{abstract}
Bamboo having multifarious utility and benefits to environment and socio-economic sustainability are grown widely either as plantations or as agroforestry woody perennial species. Although, Dendrocalamus longispathus and Schizostachyum dullooa, the two important bamboo species of North East India are cultivated as pure stands, their agroforestry potential is not known yet. Therefore, to test its allelopathic effect, different concentrations of leaf extracts of D. longispathus and S. dullooa were applied to crops such as maize and soyabean under bioassay and pot culture. The study showed that the leaf extracts of both the bamboo species did not have any inhibitory effect on the germination of maize in bioassay. In the case of soyabean, some stimulatory effect of these two bamboo species was observed in germination per cent both in bioassay as well as in pot culture. The study also revealed that the leaf extracts of $D$. longispathus reduced dry root weight of maize with $5 \mathrm{~g}+$ soil treatment by $34.29 \%$ compared to control. The highest shoot biomass of soyabean was observed at $10 \mathrm{~g}+\mathrm{soil}$. Also, $S$. dullooa extracts in pot culture showed a stimulatory effect on the root dry weight of maize at $10 \mathrm{~g}+$ soil and $20 \mathrm{~g}+$ soil treatments.. Both root and shoot dry weight of soyabean increased at high concentration of $S$. dullooa extracts. The results revealed that the soyabean was more affected than maize by these two bamboo species and S. dullooa showed more inhibition to the test crops compared to D. longispathus.
\end{abstract}

* Corresponding author

E-mail: kumzu70@gmail.com (Kalidas Upadhyaya)

Peer review under responsibility of Journal of Experimental Biology and Agricultural Sciences.

Production and Hosting by Horizon Publisher India [HPI] (http://www.horizonpublisherindia.in/).

All rights reserved.
All the articles published by Journal of Experimental Biology and Agricultural Sciences are licensed under a Creative Commons Attribution-NonCommercial 4.0 International License Based on a work at www.jebas.org.

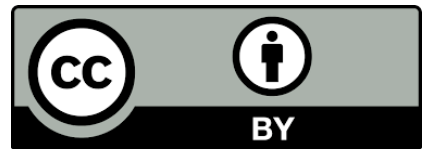




\section{Introduction}

Allelopathy is the effect caused by a plant to the surrounding plant either by deteriorating or enhancing its growth depending on its chemical present (Gibson \& Liebman, 2003; Mafeo et al., 2010). The performance of seed germination and seedling growth determines the possibility of one plant having an allelopathic effect on another plant by releasing allelochemicals, which thereafter interfere in its physiological development (Nega \& Guteda, 2019). The leaves are known to be the most influential source of allelochemicals (Kumar et al., 2006). This allelopathic effect might be positive or negative, it varies with plant species. In agroforestry, the perennial plants play a major role by providing food, fodder, fuel wood, and income by selling the woods, helps to stabilize the environment by providing shade, purify air, control erosion and enhance nutrient cycling (Sobola et al., 2015).

However, incorporation of perennial plants in agroforestry could result in unfavourable allelopathic effects on neighbouring plants (Mughal, 2000). Therefore, assessment of this effect for checking the compatibility of any tree crop is important before establishing any agroforestry systems. Bamboo based agroforestry system plays an important role in enhancing food productivity, diminished the exploitation of important timbers, provide household income and a suitable resource for biofuels (Chin et al., 2017; Akoto et al., 2018). Bamboo being fastgrowing, renewable versatile plant and the fast regrowth characteristics has proved to sequester more $\mathrm{CO}_{2}$ in a short period (Ahlawat, 2014), thus help mitigate climate change. However, the rate of carbon sequestration depends upon the age and species composition, silviculture practices, and land use system and environmental factors (Partey et al., 2017). It also enhances the degraded soil and advances the economics of developing tropical nations by securing foods (Kittur et al., 2016). D. longispathus is a clump-forming bamboo and characterized by thick culm wall $(12 \mathrm{~mm})$ and is grown naturally in the forests of North East India (Banik, 2015). It is widely found in India, Bangladesh, Myanmar and Thailand (Barooah \& Borthakur, 2003). S.dullooa has thin culm wall and is dominant bamboo species that forms the most important vegetation in the place they grow both in tropical and subtropical hills (Nath \& Das, 2010). However, there is a need to test their compatibility with associate crops for its phytotoxic effect before recommending to be a suitable crop combination for bamboobased agroforestry systems. Therefore, the current study aims to understand the allelopathic effect of $D$. longispathus and $S$. dullooa on maize and soyabean (local variety) crop based agroforestry systems. Further, effect of these two bamboo species on germination and growth behaviour of maize and soyabean crop was also evaluated during the study.

\section{Materials and Methods}

\subsection{Experimental Setup}

The study was carried out in the Forestry Department, Mizoram

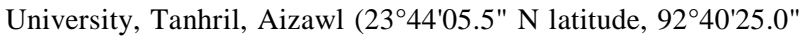
E longitude; 795 meters above sea level). Naturally shed leaves of two bamboo plant species i.e. D. longispathus and $S$. dullooa approximately 5 years of age were collected from Forest Research Centre for Bamboo and Rattan located at Bethlehem Vengthlang, Aizawl, Mizoram. The collected leaves were kept for air drying for two weeks. After drying, leaves were wiped with cloth and ground to powder with the help of grinder and passed through $0.5 \mathrm{~mm}$ mesh sieve. The sieve samples were stored in air-tight polythene bags for use in extract preparation. The aqueous extract was prepared separately for both the selected bamboo species by adding 100 gram ground leaves to $1000 \mathrm{ml}$ of distilled water which made up the ratio of 1:10 (w/v), mixed thoroughly. After 24 hours of keeping at room temperature, the extracts were obtained by filtering the solutions with Whatman filter paper No. 1.

Different concentrations were made by diluting the stock solution with distilled water viz., 5\%, $10 \%, 15 \%, 20 \%$, and $25 \%$ respectively. Before use, surface sterilization of the maize and soyabean seeds was done by sodium hypochlorite $(0.1 \%)$ for two minutes followed by rinsing with tap water. Twenty treated seeds of each food crops were kept in Petri-plates after sterilizing (hot air oven at $120^{\circ} \mathrm{C}$ ) containing the filter paper and saturated with respective concentration except control treatment (with distilled water). Seed germination, shoot and root extension were measured and recorded after 21 days of sowing. In the case of poly pot experiment, the ground leaves (henceforth, will be termed as leaf extract) were thoroughly mixed with $5 \mathrm{~kg}$ of soil per pot and different treatments were prepared viz., $5 \mathrm{~g}+$ soil, $10 \mathrm{~g}+$ soil, $15 \mathrm{~g}+$ soil, $20 \mathrm{~g}+$ soil, $25 \mathrm{~g}+$ soil, for both the bamboo species. Soil without amendment with grounded leaf was taken as control. Ten seeds each of maize and soyabean were sown in each poly pot and irrigated with water. At 3-4 leaf stage after germination, the best performing plant was selected and retained while others were removed from the polypot. Germination percentage and other growth parameters were recorded after two months of sowing. The following formulae were used for obtaining percentage of germination and inhibition or stimulation (Surendra \& Pota, 1978):

GP $($ Germination percent $)=$

Seed germinated/Total seeds sown $\times 100$

Inhibition or Stimulation Percentage $=$

[(Control value- Treatment value $) /$ control value $] \times 100$. 


\subsection{Statistical analysis}

Data were subjected to analysis of variance and the mean values were compared using Duncan's Multiple Range Test at $5 \%$ and $1 \%$ probability level. Statistical analysis was done using SPSS version 20.

\section{Results and discussions}

\subsection{Bioassay}

\subsubsection{Germination}

The aqueous leaf extracts of $D$. longispathus and $S$. dullooa were found to stimulate the germination percentage of maize with increased concentration which was recorded $96.67 \%$ and $93.33 \%$ at $15 \%$ concentration of D. Longispathus and S. Dullooa respectively, however this difference was not found significant $(p \leq 0.05)$. On the other hand, both the bamboo species inhibited the germination rate of soyabean seed which was recorded highest at $10 \%(83.33 \%)$ and $25 \%(88.33 \%)$ concentrations respectively (Table 1). This finding agreed with Abugre et al. (2011), where the root extract of Sennasiamea increased the germination of Zea mays and Lycopersicon esculentum. Further, Suseelamma \& Venkata (1994) stated that the inhibition of germination might be the resultant effect of allelochemicals that are water-soluble entering into the seed, which retard germination and growth. The findings also conform to the report of Nega \& Gudeta (2019) where aqueous extracts of Eucalyptus globules inhibited the germination and seedling growth of highland teff and barley at different concentrations.

\subsubsection{Root and Shoot Elongation}

The extracts of $D$. longispathus stimulated maize root and shoot elongation whereas highest stimulatory effect on root length $(+26.47 \%)$ and shoot length $(+144.50 \%)$ was observed at $25 \%$ concentration of $D$. longispathus (Table 2), these findings are in

Table 1 Effect of aqueous leaf extracts of $D$. longispathus and $S$. dullooa on germination rate of maize and soyabean in bioassay and pot culture.

\begin{tabular}{|c|c|c|c|c|c|c|c|c|c|}
\hline \multirow[t]{3}{*}{ Treatments } & \multicolumn{4}{|c|}{ Bioassay (21 DAS) } & \multirow[t]{3}{*}{ Treatments } & \multicolumn{4}{|c|}{ Pot culture (60 DAS) } \\
\hline & \multicolumn{2}{|c|}{ D. longispathus } & \multicolumn{2}{|c|}{ S. dullooa } & & \multicolumn{2}{|c|}{ D. longispathus } & \multirow{2}{*}{$\begin{array}{c}\text { S. dullooa } \\
\text { Maize } \\
(\%)\end{array}$} & \multirow[b]{2}{*}{$\begin{array}{c}\text { Soyabean } \\
(\%)\end{array}$} \\
\hline & $\begin{array}{l}\text { Maize } \\
(\%)\end{array}$ & $\begin{array}{c}\text { Soyabean } \\
(\%)\end{array}$ & $\begin{array}{c}\text { Maize } \\
(\%)\end{array}$ & $\begin{array}{c}\text { Soyabean } \\
(\%)\end{array}$ & & $\begin{array}{l}\text { Maize } \\
(\%)\end{array}$ & $\begin{array}{c}\text { Soyabean } \\
(\%)\end{array}$ & & \\
\hline Control & 88.33 & 95.00 & 81.67 & 90.00 & Control & 93.33 & 60.00 & 93.33 & 70.00 \\
\hline $5 \%$ & 88.33 & 90.00 & 91.67 & 88.33 & $5 g+$ soil & 93.33 & 56.67 & 96.67 & 56.67 \\
\hline $10 \%$ & 90.00 & 83.33 & 90.00 & 95.00 & $10 \mathrm{~g}+$ soil & 90.00 & 53.33 & 93.33 & 63.33 \\
\hline $15 \%$ & 96.67 & 90.00 & 93.33 & 90.00 & $15 \mathrm{~g}+$ soil & 83.33 & 60.00 & 93.33 & 73.33 \\
\hline $20 \%$ & 91.67 & 95.00 & 85.00 & 90.00 & $20 \mathrm{~g}+$ soil & 96.67 & 66.67 & 90.00 & 56.67 \\
\hline $25 \%$ & 93.33 & 93.33 & 91.67 & 88.33 & $25 \mathrm{~g}+$ soil & 83.33 & 66.67 & 83.33 & 46.67 \\
\hline SEM \pm & NS & NS & NS & NS & SEM \pm & NS & NS & NS & NS \\
\hline
\end{tabular}

$\mathrm{SEM} \pm=$ Standard error of means; NS=not significant

Table 2 Effect of aqueous leaf extracts of $D$. longispathus and $S$. dullooa on root and shoot elongation of maize and soyabean after 21 DAS in bioassay.

\begin{tabular}{|c|c|c|c|c|c|c|c|c|c|c|c|c|}
\hline \multirow{3}{*}{ Treatment } & \multicolumn{6}{|c|}{ D. longispathus } & \multicolumn{6}{|c|}{ S. dullooa } \\
\hline & \multicolumn{3}{|c|}{ Maize } & \multicolumn{3}{|c|}{ Soyabean } & \multicolumn{3}{|c|}{ Maize } & \multicolumn{3}{|c|}{ Soyabean } \\
\hline & $\begin{array}{l}\text { Root } \\
\text { length } \\
(\mathrm{cm})\end{array}$ & $\begin{array}{l}\text { Shoot } \\
\text { length } \\
(\mathrm{cm})\end{array}$ & $\begin{array}{l}\text { Root: } \\
\text { Shoot } \\
\text { ratio }\end{array}$ & $\begin{array}{l}\text { Root } \\
\text { length } \\
(\mathrm{cm})\end{array}$ & $\begin{array}{l}\text { Shoot } \\
\text { length } \\
(\mathrm{cm})\end{array}$ & $\begin{array}{l}\text { Root: } \\
\text { Shoot } \\
\text { ratio }\end{array}$ & $\begin{array}{l}\text { Root } \\
\text { length } \\
(\mathrm{cm})\end{array}$ & $\begin{array}{l}\text { Shoot } \\
\text { length } \\
(\mathrm{cm})\end{array}$ & $\begin{array}{l}\text { Root: } \\
\text { Shoot } \\
\text { ratio }\end{array}$ & $\begin{array}{l}\text { Root } \\
\text { length } \\
(\mathrm{cm})\end{array}$ & $\begin{array}{c}\text { Shoot } \\
\text { length } \\
(\mathrm{cm})\end{array}$ & $\begin{array}{l}\text { Root: } \\
\text { Shoot } \\
\text { ratio }\end{array}$ \\
\hline Control & 5.44 & 3.64 & $1.54^{\mathrm{b}}$ & $6.36^{\mathrm{a}}$ & $14.96^{\mathrm{a}}$ & 0.46 & 5.41 & 3.64 & 1.54 & 6.35 & 14.96 & 0.46 \\
\hline $5 \%$ & 5.84 & 3.82 & $1.64^{b}$ & $6.83^{\mathrm{ab}}$ & $20.25^{b}$ & 0.34 & 4.76 & 2.84 & 1.69 & 5.85 & 10.61 & 0.55 \\
\hline $10 \%$ & 5.92 & 5.81 & $1.11^{\mathrm{ab}}$ & $6.29^{\mathrm{a}}$ & $23.84^{\mathrm{c}}$ & 0.27 & 5.07 & 2.28 & 2.25 & 6.11 & 12.34 & 0.52 \\
\hline $15 \%$ & 5.48 & 5.97 & $0.92^{\mathrm{a}}$ & $5.95^{\mathrm{a}}$ & $13.57^{\mathrm{a}}$ & 0.44 & 5.73 & 6.28 & 1.60 & 5.81 & 14.31 & 0.41 \\
\hline $20 \%$ & 5.57 & 4.94 & $1.24^{\mathrm{ab}}$ & $6.84^{\mathrm{ab}}$ & $17.41^{\mathrm{ab}}$ & 0.39 & 5.48 & 3.46 & 1.85 & 6.05 & 14.48 & 0.42 \\
\hline $25 \%$ & 6.88 & 8.90 & $0.77^{\mathrm{a}}$ & $7.63^{\mathrm{b}}$ & $17.40^{\mathrm{ab}}$ & 0.44 & 5.75 & 2.67 & 2.44 & 5.87 & 12.97 & 0.46 \\
\hline SEM \pm & NS & NS & $0.09^{*}$ & $0.17 *$ & $0.93 * *$ & NS & NS & NS & NS & NS & NS & NS \\
\hline
\end{tabular}

$\mathrm{SEM} \pm=$ Standard error of means; $\mathrm{NS}=$ not significant; $\mathrm{p}<0.05=$ significant at $5 \% * ; \mathrm{p}<0.01=$ significant at $1 \%$ **; same symbols in superscript do not differ significantly $(\mathrm{p}<0.05)$

Journal of Experimental Biology and Agricultural Sciences http://www.jebas.org 
agreement with the results of Stachon \& Zimdahl (1980) and Rejila \& Vijayakumar (2011). The study revealed that the root length of soyabean is less affected at the higher concentration of $D$. longispathus leaf extracts, thereby showing the highest significant stimulatory effect at $25 \%(+19.96 \%)$. The above finding is in agreement of the result of Lalremsang et al. (2017) where lateral roots of maize showed stimulatory effect at higher concentration of Schimawallichi and Mesuaferrea leaf extracts when compared to control in a pot experiment.

Similar to D. longispathus, the highest concentration (25\%) of $S$. Dullooa leaf extracts also had a stimulatory effect on root length of maize $(+6.28 \%)$ for $S$. Dullooa, however, the leaf extract of the same species showed inhibitory effect on shoot length of maize, the highest being at $10 \%$ concentration $(-37.36 \%)$ (Table 2). The results of Saboya \& Borghetti (2012) are in agreement with the results of the present study where seedling's mean root length of Copaifera langsdorffii and Dioscorea alata were enhanced by four times compared to mean shoot length. However, the aqueous leaf extracts of $S$. dullooa showed an inhibitory effect on the root and shoot length of soyabean. The highest inhibition was observed at $15 \%(-14.79 \%)$ and $5 \%(-29.07 \%)$ concentrations for root and shoot respectively (Table 2). This might be due to the interference of phytohormones of the food crops by chemicals present in the extract (Cheng \& Cheng, 2016). This finding is also at par with the findings by Jash et al. (2019) where Chromolaena adolata significantly reduces the grass pea's root and shoot length as well as its biomass in the bioassay experiment.

\subsection{Pot culture}

\subsubsection{Germination percentage}

All treatments of $D$. longispathus extract except $20 \mathrm{~g}+$ soil inhibited seed germination in maize when compared to control. Similar to maize, it also had an inhibitory effect on the soyabean seed germination and among the tested treatments $20 \mathrm{~g}+$ soil and $25 \mathrm{~g}+$ soil had higher seed germination than the control (Table 1). These findings are similar to the findings of Rafigul Hoque et al. (2003), where the germination rate of Brassica juncea, Phaseolus mungo, Raphanus sativus, Vigna unguilata, and Cicer arietinum were inhibited highly with increase of extract concentration in Acacia auriculiformis. These results are in agreement with the findings of Thakur et al. (2017) those who reported inhibitory effect of Melia dubia leaf extracts and litter on germination and growth of green gram and black chickpea.

Further, S. dullooa leaf extracts reduced seed germination in both maize and soyabean crop. The inhibitory effect was concentrationdependent. Maximum inhibitory effect was observed at 25g+soil for both maize and soyabean when compared to control (Table 1). These findings are similar to findings reported by Mandal et al. (2016), Wu et al. (2015), Nath et al. (2016), where inhibition may be caused by occurrence of nutrients, growth regulators, alkaloids and toxins in the leaf leachates that causes retardation of seed germination and seedling growth.

\subsubsection{Root and shoot elongation}

The leaf extracts of $D$. longispathus showed stimulatory effect with increased in concentration for both root and shoot length of maize, wherein significant stimulatory effect for shoot length was observed at $25 \mathrm{~g}+$ soil $(+28.64 \%)$. However, D. Longispathus extracts had retarding effect on the root as well as shoot length of soyabean and this effect was found concentration dependent. The maximum inhibition was observed at 20g+soil $(-10.66 \%)$ and $25 \mathrm{~g}+$ soil $(-8.28 \%)$ for root as well as shoot length respectively (Table 3). The above results conform to the result given by Salama \& Rabiah (2015) where the low concentrations of aqueous extract of $C$. colocynthis had a stimulatory effect while higher concentration induced greater inhibition on root and shoot length of Hordeum vulgare.

Table 3 Effect of leaf extracts of D. longispathusand S. dullooa on Shoot \& Root elongation of maize and soyabean after 60 DAS in pot culture.

\begin{tabular}{|c|c|c|c|c|c|c|c|c|c|c|c|c|}
\hline \multirow[t]{3}{*}{ Treatment } & \multicolumn{6}{|c|}{ D. longispathus } & \multicolumn{6}{|c|}{ S. dullooa } \\
\hline & \multicolumn{3}{|c|}{ Maize } & \multicolumn{3}{|c|}{ Soyabean } & \multicolumn{3}{|c|}{ Maize } & \multicolumn{3}{|c|}{ Soyabean } \\
\hline & $\begin{array}{l}\text { Root } \\
\text { length } \\
(\mathrm{cm})\end{array}$ & $\begin{array}{l}\text { Shoot } \\
\text { length } \\
(\mathrm{cm})\end{array}$ & $\begin{array}{l}\text { Root: } \\
\text { Shoot } \\
\text { ratio }\end{array}$ & $\begin{array}{c}\text { Root } \\
\text { length } \\
(\mathrm{cm})\end{array}$ & $\begin{array}{l}\text { Shoot } \\
\text { length } \\
(\mathrm{cm})\end{array}$ & $\begin{array}{l}\text { Root: } \\
\text { Shoot } \\
\text { ratio }\end{array}$ & $\begin{array}{c}\text { Root } \\
\text { length } \\
(\mathrm{cm})\end{array}$ & $\begin{array}{l}\text { Shoot } \\
\text { length } \\
(\mathrm{cm})\end{array}$ & $\begin{array}{l}\text { Root: } \\
\text { Shoot } \\
\text { ratio }\end{array}$ & $\begin{array}{c}\text { Root } \\
\text { length } \\
(\mathrm{cm})\end{array}$ & $\begin{array}{l}\text { Shoot } \\
\text { length } \\
(\mathrm{cm})\end{array}$ & $\begin{array}{l}\text { Root: } \\
\text { Shoot } \\
\text { ratio }\end{array}$ \\
\hline Control & 50.80 & $53.07^{\mathrm{b}}$ & 0.96 & 61.20 & 44.67 & 1.39 & 61.27 & 61.40 & 1.05 & 55.47 & 50.47 & 1.18 \\
\hline $5 \mathrm{~g}+$ soil & 59.30 & $42.80^{\mathrm{a}}$ & 1.39 & 61.23 & 43.73 & 1.46 & 82.37 & 70.83 & 1.15 & 53.00 & 61.23 & 0.89 \\
\hline $10 \mathrm{~g}+$ soil & 54.63 & $63.17^{\mathrm{ab}}$ & 0.89 & 67.07 & 45.67 & 1.51 & 60.50 & 59.83 & 1.02 & 59.30 & 60.50 & 1.03 \\
\hline $15 \mathrm{~g}+$ soil & 62.83 & $62.07^{\mathrm{ab}}$ & 1.02 & 54.67 & 43.37 & 1.27 & 72.93 & 74.17 & 1.00 & 57.77 & 59.37 & 1.01 \\
\hline $20 \mathrm{~g}+$ soil & 73.17 & $56.53^{\mathrm{b}}$ & 1.29 & 55.83 & 42.63 & 1.33 & 79.63 & 60.60 & 1.31 & 50.47 & 54.03 & 0.99 \\
\hline $25 \mathrm{~g}+$ soil & 77.03 & $68.27^{\mathrm{c}}$ & 1.12 & 56.47 & 40.97 & 1.41 & 68.87 & 72.40 & 0.94 & 56.70 & 55.87 & 1.03 \\
\hline SEM \pm & NS & $2.27 * *$ & NS & NS & NS & NS & NS & NS & NS & NS & NS & NS \\
\hline
\end{tabular}

SEM $\pm=$ Standard error of means; NS=not significant; $\mathrm{p}<0.01=$ significant at $1 \% * *$; same symbols in superscript do not differ significantly ( $<<0.01$ )

Journal of Experimental Biology and Agricultural Sciences

http://www.jebas.org 
Like D. Longispathus, the leaf extract of $S$. dullooa also had an inhibitory effect of the root length of maize and maximum root inhibition was reported at the highest concentration of $S$. dullooa while in case of shoot length it showed concentration dependent effect. The highest stimulatory effect for root length was observed at the lowest concentration $(+34.43 \%)$ which was followed by $20 \mathrm{~g}+\mathrm{soi}$ (+29.96) (Table 3). Results are in agreement with the findings of Sisodia \& Siddiqui (2010), who reported reduction in radical, plumule length and dry weight of test seedlings with Croton bonplandianum extracts application. Altering the $\mathrm{pH}$ and osmotic potential of extracts causes inhibitory effects (Sisodia \& Siddiqui 2008). In soyabean, the root length growth was highly affected by the leaf extracts of $S$. dullooa. The maximum inhibitory effect on root growth was observed at $5 \mathrm{~g}+$ soil $(-4.45 \%)$ and $20 \mathrm{~g}+$ soil concentration of $S$. dullooa $(-9.01 \%)$. These results confirm the findings of Barkosky $\&$ Einhellig (2003), where seedlings growth of soyabean was reduced with increasing concentrations of hydroxy benzoic acid (allelochemicals) under greenhouse condition. Similar findings had been observed by Kumar et al. (2019) on wheat by Anthocephalus cadamba and Melia dubia leaf extracts.

\subsubsection{Biomass}

The study showed that extracts of $D$. longispathus inhibit the dry root weight of maize in all the treatments when compared to control (Table 4). Similar to these results, Namkeleja et al. (2013) also reported that the $A$. mexicana seed and leaf extracts reduced both the fresh and dry weight of $B$. dictyoneura as concentration increased. This may be due to the presence of allelochemicals that inhibit the synthesis of protein along with carbohydrates, thereby growth inhibited. In soyabean, the dry weight of root and shoot increased amid high extract concentration compared to control. The highest shoot biomass was observed at $10 \mathrm{~g}+$ soil $(+23.40 \%)$ and $25 \mathrm{~g}+$ soil tretments $(+10.63 \%)$ (Table 4). A similar result was observed by Khan et al. (2007), who reported that Eucalyptus extracts had a stimulatory effect on dry root and shoot weight of maize which may be due to its oil having antiseptic properties that might help in increase root, shoot length and weight. Further, similar results were observed by Lalremsang et al. (2018) where the aqueous leaf extracts of Flemingia semialata showed a stimulatory effect on the biomass of maize.

The leaf extract of $S$. dullooa exhibited a higher inhibitory effect on root dry weight than shoot dry weight of maize where the highest reduction of root dry mass was observed at $10 \mathrm{~g}+$ soil and $20 \mathrm{~g}+$ soil treatments $(-22.91 \%)$ (Table 5). Similar results were reported by Namkeleja et al. (2013), these researchers evaluated the allelopathic effect of Argemone mexicana on roots and shoot dry

Table 4 Effect of leaf extracts of D. longispathus on dry mass production of maize and soyabean after 60 DAS in pot culture.

\begin{tabular}{|c|c|c|c|c|c|c|c|c|c|c|}
\hline \multirow{3}{*}{ Treatment } & \multicolumn{5}{|c|}{ Maize } & \multicolumn{5}{|c|}{ Soyabean } \\
\hline & \multicolumn{2}{|c|}{ Fresh weight (g) } & \multicolumn{2}{|c|}{ Dry weight (g) } & \multirow{2}{*}{$\begin{array}{l}\text { Dry root: } \\
\text { shoot Ratio }\end{array}$} & \multicolumn{2}{|c|}{ Fresh weight (g) } & \multicolumn{2}{|c|}{ Dry weight (g) } & \multirow{2}{*}{$\begin{array}{l}\text { Dry root: } \\
\text { shoot Ratio }\end{array}$} \\
\hline & Root & Shoot & Root & Shoot & & Root & Shoot & Root & Shoot & \\
\hline Control & 2.52 & $2.87^{\mathrm{a}}$ & 0.35 & $0.57^{\mathrm{ab}}$ & $0.32^{\mathrm{a}}$ & $0.71^{\mathrm{a}}$ & 1.76 & 0.18 & 0.47 & 0.38 \\
\hline $5 \mathrm{~g}+$ soil & 2.40 & $2.51^{\mathrm{a}}$ & 0.23 & $0.27^{\mathrm{a}}$ & $0.86^{\mathrm{c}}$ & $1.42^{\mathrm{b}}$ & 2.16 & 0.23 & 0.49 & 0.48 \\
\hline $10 g+$ soil & 4.23 & $6.44^{\mathrm{bc}}$ & 0.35 & $0.78^{\mathrm{bc}}$ & $0.33^{\mathrm{a}}$ & $1.46^{\mathrm{b}}$ & 2.47 & 0.25 & 0.58 & 0.44 \\
\hline $15 \mathrm{~g}+$ soil & 4.29 & $4.09^{\mathrm{a}}$ & 0.27 & $0.44^{\mathrm{ab}}$ & $0.72^{\mathrm{bc}}$ & $1.33^{\mathrm{b}}$ & 2.18 & 0.25 & 0.51 & 0.50 \\
\hline $20 g+$ soil & 2.61 & $4.71^{\mathrm{ab}}$ & 0.22 & $0.41^{\mathrm{ab}}$ & $0.50^{\mathrm{ab}}$ & $0.82^{\mathrm{a}}$ & 2.13 & 0.20 & 0.45 & 0.43 \\
\hline $25 \mathrm{~g}+$ soil & 3.94 & $7.78^{\mathrm{c}}$ & 0.34 & $0.96^{\mathrm{c}}$ & $0.27^{\mathrm{a}}$ & $0.74^{\mathrm{a}}$ & 1.76 & 0.24 & 0.52 & 0.45 \\
\hline SEM \pm & NS & $0.51 * *$ & NS & $0.07 * *$ & $0.06^{* * *}$ & $0.09 * *$ & NS & NS & NS & NS \\
\hline
\end{tabular}

$\mathrm{SEM} \pm=$ Standard error of means; NS=not significant; $\mathrm{p}<0.01=$ significant at $1 \%{ }^{* *}$; same symbols in superscript do not differ significantly $(\mathrm{p}<0.01)$

Table 5 Effect of leaf extracts of $S$. dullooa on dry mass production of maize and soyabean in pot culture.

\begin{tabular}{|c|c|c|c|c|c|c|c|c|c|c|}
\hline \multirow{3}{*}{ Treatment } & \multicolumn{5}{|c|}{ Maize } & \multicolumn{5}{|c|}{ Soyabean } \\
\hline & \multicolumn{2}{|c|}{ Fresh weight (g) } & \multicolumn{2}{|c|}{ Dry weight (g) } & \multirow{2}{*}{$\begin{array}{c}\text { Dry root: } \\
\text { shoot Ratio }\end{array}$} & \multicolumn{2}{|c|}{ Fresh weight (g) } & \multicolumn{2}{|c|}{ Dry weight (g) } & \multirow{2}{*}{$\begin{array}{c}\text { - Dry oot: } \\
\text { shoot Ratio }\end{array}$} \\
\hline & Root & Shoot & Root & Shoot & & Root & Shoot & Root & Shoot & \\
\hline Control & 4.23 & 4.44 & 0.48 & 0.66 & 0.75 & $1.25^{\mathrm{a}}$ & 2.09 & 0.20 & 0.53 & 0.39 \\
\hline $5 g+$ soil & 5.39 & 7.22 & 0.43 & 0.95 & 0.46 & $1.50^{\mathrm{a}}$ & 2.31 & 0.19 & 0.58 & 0.34 \\
\hline $10 \mathrm{~g}+$ soil & 3.96 & 4.06 & 0.37 & 0.67 & 0.58 & $2.01^{\mathrm{ab}}$ & 2.47 & 0.20 & 0.56 & 0.39 \\
\hline $15 \mathrm{~g}+$ soil & 5.23 & 7.09 & 0.57 & 1.00 & 0.58 & $1.97^{\mathrm{ab}}$ & 2.37 & 0.23 & 0.53 & 0.44 \\
\hline $20 \mathrm{~g}+$ soil & 3.07 & 5.27 & 0.37 & 0.81 & 0.47 & $2.02^{\mathrm{ab}}$ & 2.41 & 0.21 & 0.55 & 0.38 \\
\hline $25 \mathrm{~g}+$ soil & 4.88 & 7.37 & 0.55 & 1.05 & 0.54 & $2.46^{\mathrm{b}}$ & 2.40 & 0.32 & 1.07 & 0.31 \\
\hline SEM \pm & NS & NS & NS & NS & NS & $0.12 *$ & NS & NS & NS & NS \\
\hline
\end{tabular}

$\mathrm{SEM} \pm=$ Standard error of mean; NS=not significant; $\mathrm{p}<0.05=$ significant at $5 \% *$; same symbols in superscript do not differ significantly ( $<<0.05$ ).

Journal of Experimental Biology and Agricultural Sciences

http://www.jebas.org 

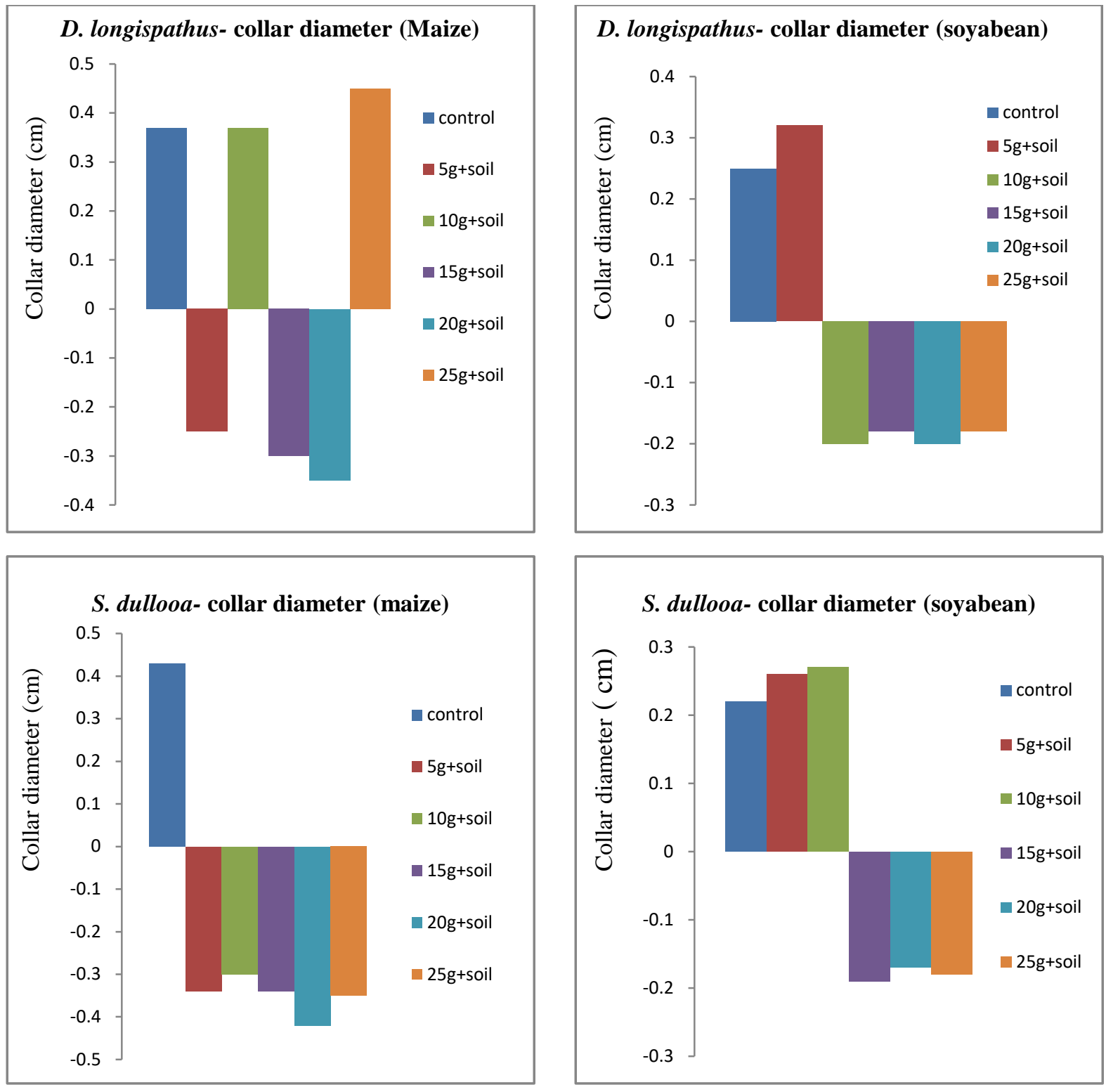

Figure 1 Effect of leaf extracts of D. longispathus and $S$. dullooaon collar diameter of maize and soyabean under pot culture experiment. $(+)$ indicates stimulatory and $(-)$ indicates inhibitory.

weight of Brachiaria dictyoneura and Clitoria ternatea and found that root growth was severely affected than shoot growth. On the contrary, enhanced root and shoot dry weight of soyabean was recorded at high concentration. The highest stimulatory effects of root $(+60.00 \%)$ and shoot $(+101.89 \%)$ biomass were observed in the treatment with $25 \mathrm{~g}+$ soil (Table 5). The above results were at par with the findings of Wu et al. (2015) who reported that extracts of Mikania micrantha promoted the dry weight of shoot, root as well as leaf area of test crops.

\subsubsection{Collar diameter and number of leaves}

The leaf extracts of $D$. longispathus showed an inhibitory effect on the collar diameter of maize and soyabean crops. The highest inhibition on collar diameter was observed at lower concentration (5g+soil) for maize and for soyabean at $15 \mathrm{~g}+$ soil while the highest concentration $(25 \mathrm{~g}+\mathrm{soil})$ of $D$. longispathus had stimulatory effect on the collar diameter of maize. In the case of soyabean the highest enhancement in collar diameter was observed at a lower concentration of 10g+soil (Figure 1). Maximum number of leaves 


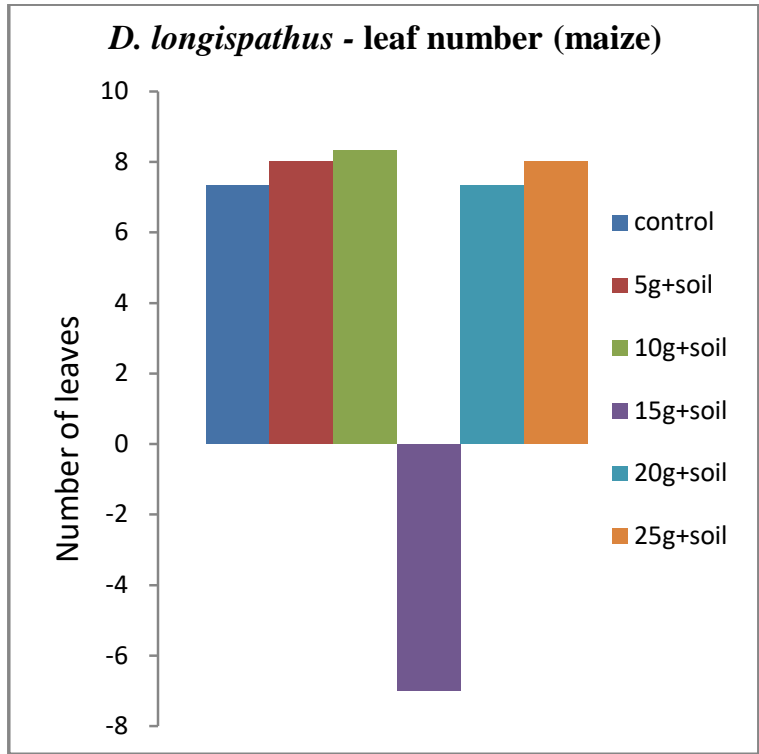

S. dullooa - leaf number (maize)

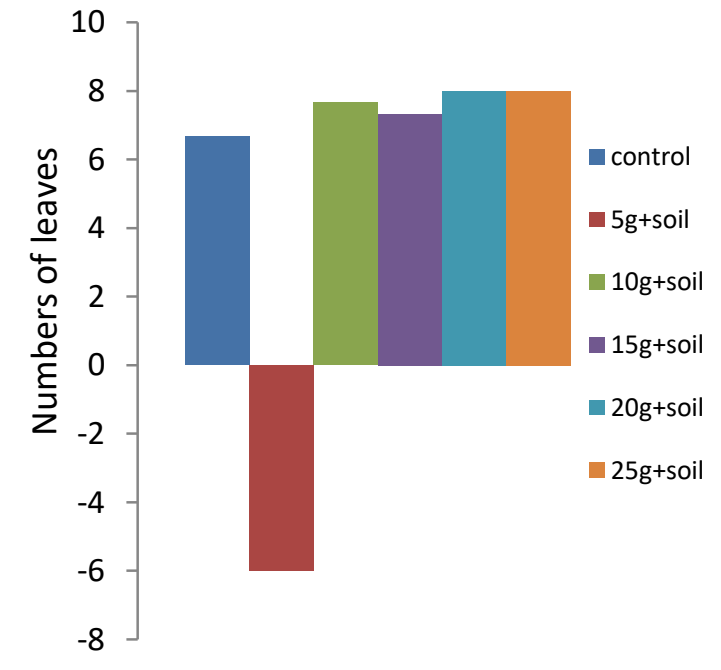

\section{D. longispathus - leaf number (soyabean)}

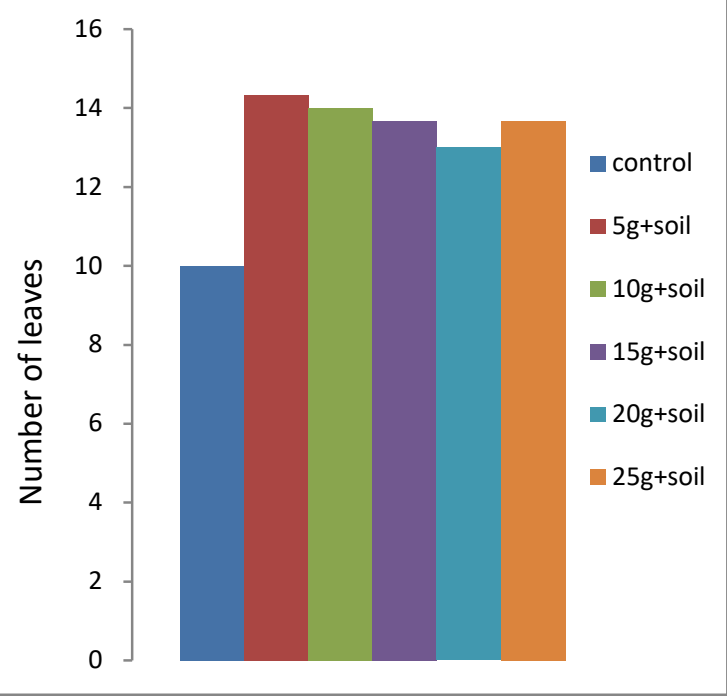

S. dullooa - leaf number (soyabean)

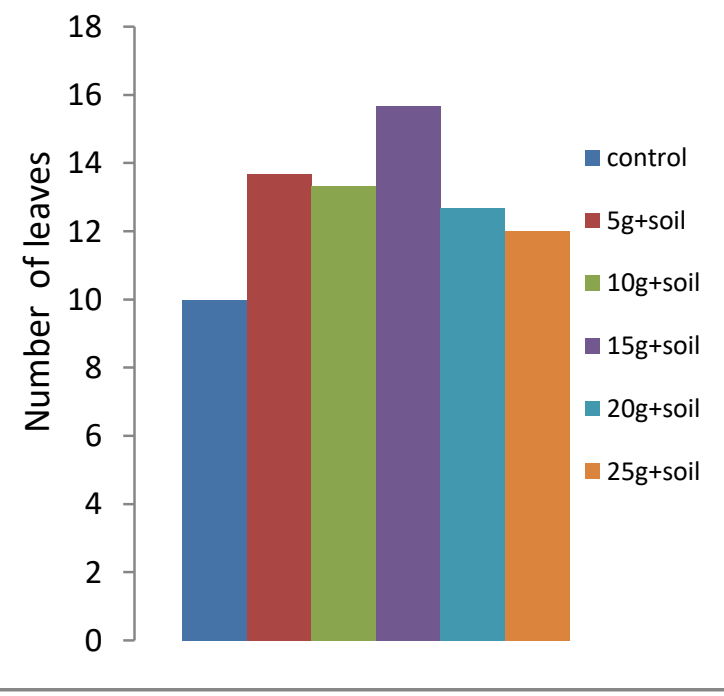

Figure 2 Effect of leaf extracts of D. longispathus and S. dullooaon leaf number of maize and soyabean under pot culture experiment.

was recorded in lower concentrations than the higher concentration of extracts in both the test crops (Figure 2). Previous research of Ahmed et al. (2018) also gave similar results on these aspects who concluded that the leaf litter of $E$. camaldulensis negatively reduced the collar diameters and leaf number with increasing concentration of leaf litter.

Similarly, leaf extracts of $S$. dullooa prominently reduced the collar diameter. The highest inhibitory effects were observed at $10 \mathrm{~g}+$ soil and $20 \mathrm{~g}+$ soil concentration in maize and soyabean respectively (Figure 1). The number of leaves was found to be increased in all concentrations of extracts when compared to control (Figure 2). These observations agreed with the findings of Adetayo et al. (2005) and Abu-Romman (2011), who suggested that leaf number, was significantly influenced by the allelochemicals of Chromolaena odorata and Achillea biebersteinii. Kumar et al. (2018) also reported reduce collar diameter of maize with the application of Melia dubia leaf extracts.

\section{Conclusions}

The results of the experiment revealed that the leaf extracts of $D$. longispathus and $S$. dullooa had pronounced effect on soyabean in terms of germination percent, and growth parameters compared to maize crops. It can also be concluded from the study that $S$. 
dullooa leaf extracts has a higher inhibitory effect than the $D$. longispathus on the test crops. The allelochemicals from bamboo leaves influenced the germination percent, growth parameters differently on the same crop. Therefore, there is a need to determine the types of allelochemicals present in the bamboo species which might have regulated the stimulatory as well as inhibitory effects on the test crops before recommending the two bamboo species as potential woody perennial to be used in agroforestry systems.

\section{Acknowledgements}

The authors are grateful to the members of the Forest Research Centre for Bamboo and Rattan, Bethlehem Aizawl, Mizoram for allowing the collection of bamboo leaves and also to the Head, Department of Forestry for permitting us to use the necessary instruments required for the completion of the research work. Thanks are also to Dr. J.K. Chaudhary, Department of Animal Breeding and Genetics, College of Veterinary Sciences and Animal Husbandry, Central Agricultural University, Selesih for his help in analysing the data with statistical softwares.

\section{Conflict of Interest}

The authors declare that there is no conflict of interest.

\section{References}

Abugre S, Apetorgbor AK, Antwiwaa A, Apetorgbor MM (2011) Allelopathic effects of ten tree species on germination and growth of four traditional food crops in Ghana. Journal of Agriculture Technology 7: 825-834.

Abu-Romman S (2011) Allelopathic potential of Achillea biebersteinii Afan. (Asteraceae).World Applied Sciences Journal 15: 947-952.

Adetayo OB, Lawal OI, Alabi BS, Owolade OF (2005) Allelopathic Effect of Siam Weed (Chromolaena odorata) on Seed Germination and Seedling Performance of Selected Crop and Weed Species. In: proceeding of the $4^{\text {th }}$ world congress on allelopathy," Establishing the scientific base", held at waggawagga, new South Wales, Australia on 21-26 August, 2005.

Ahlawat SP (2014) Bamboo based agroforestry for livelihood security and environment protection in semi arid region of India. In: World Congress on Agroforestry, 10-14 ${ }^{\text {th }}$ February, 2014.

Ahmed R, Alam MS, Ahmed FU, Hossain MK (2018) Assaying the allelopathic effects of Eucalyptus camaldulensis in a nursery bed incorporated with leaf litter. Journal of Forestry Research 29: 593-599.

Akoto D, Denich M, Partey S, Frith O, Kwaku M, Mensah A, Borgemeister C (2018) Socioeconomic indicators of bamboo use for agroforestry development in the dry semi-deciduous forest zone of Ghana. Sustainability 10: 2324.

Banik RL (2015) Flowering nature of Dendrocalamus longispathus (Kurz) with notes on seedling and other planting materials for raising planting. Indian Forester 141: 920-929.

Barkosky RR, Einhellig FA (2003) Allelopathic interference of plant-alter relationships by Para-Hydroxy-benzoic Acid. Botanical Bullentin of Academia Sinica 44: 53-58.

Barooah C, Borthakur SK (2003) Diversity and distribution of bamboos in Assam. Bishen Singh Mahendra Pal Singh (BSMPS), Dehradun, India.

Cheng F, Cheng Z (2016) Research progress on the use of plant allelopathy in agriculture and the physiological and ecological mechanisms of allelopathy. Frontiers in Plant Science 6: 1020.

Chin KL, Ibrahim S, Hakeem KR, San H'ng P, Lee SH, Lila MAM (2017) Bioenergy production from bamboo: Potential source from Malaysia's Perspective. Bioresources 12: 6844- 6867.

Gibson LR, Liebman M (2003) A laboratory exercise for teaching plant interference and relative growth rate concepts. Weed Technology 1792: 394-402.

Jash A, Halder S, Bhattacharjee A (2019) Assessment of allelopathic potential of Chromolaena odorata (L.) King and Robinson by physiochemical approach. Research Journal of Life Sciences, Bioinformatics, Pharmaceutical and Chemical Sciences 5: 21-30.

Khan MA, Hussian I, Khan IA (2007) Effect of aqueous leaf extracts of Eucalyptus camadulensis L. on germination and growth of maize (Zea mays L.). Pakistan Journal of Weed Science Research 13: 177-182.

Kittur BH, Sudhakara K, Kumar BM, Kunhamu TK, Suresh Kumar P (2016) Bamboo based agroforestry system in Kerela, India: performance of turmeric (Curcuma longa L.) in the subcanopy of differentially spaced seven year-old bamoo stand. Agroforestry Systems 90: 237-250.

Kumar M, Lakiang JJ, Gopichand B (2006) Phytotoxic effects of agroforestry tree crops on germination and radical growth of some food crops of Mizoram. Lyonia 11: 83-89.

Kumar N, Handa AK, Dev I, Ram A, Chand L, Shukla A (2018) Allelopathic effect of aqueous leaf extract of Meliadubia on seed germination and growth of Zea mays. Bulletin of Environment, Pharmacology and Life Sciences 7:55-60.

Kumar N, Kamini AR, Handa AK, Dev I, Chand L, Shukla A, Kumar D (2019) Allelopathic effect of Anthocephalusc adamba 
(Roxb.)Miq. And Melia dubia Cav. on Triticum aestivum L.: Bioassay study. Journal of Pharmacognosy and Phytochemistry 8:1265-1269.

Lalremsang P, Gopichand B, Upadhyaya K (2018) Evaluation for performance of maize and rice on aqueous leaf extracts of Flemingia semialata Robx. - underutilized legumes in Mizoram, India. Indian Journal of Agricultural Research 52: 671-675.

Lalremsang P, Remlalpeka C, Upadhyaya K, Gopichand B (2017) Allelopathic Potential of Mesua ferrea L. and Schima wallichi Reinw.ex Blume Leaf Extracts on Seedling Growth of Maize (Zea mays L.). International Journal of Current Microbiology and Applied Sciences 6:2248-2255.

Mafeo TP, Mashela PW, Mphosi MS (2010) Allelopathy responses of various seeds to crude extracts of Cucumis myriocarpus fruits when used as a pre-emergent bio- nematicide. In: XXVIII International Horticulture Congress on Science and Horticulture for People (IHC): International symposium on environmental, edaphic and genetic factors affecting plants, seeds and turfgrass, held at Lisbon, Portugal on 22 to 27 August, 2010, 938: 409-414.

Mandal MP, Vivekanand Pal, Kumar K, Mandal SK (2016) Allelopathic effects of leaf extracts of Kamegh on seed germination and seedling growth of wheat (Triticum aestivum L.). Journal of Botanical Sciences 5:50-53.

Mughal AH (2000) Allelopathy effect of leaf extracts of Moru salba L. on germination and seedling growth of some pulses. Range Management and Agroforestry 21: 164-169.

Namkeleja HS, Tarimo MT, Patrick AN (2013) Allelopathic Effect of Aqueous Extract of Argemone mexicana L on Germination and Growth of Brachiaria dictyoneura L and Clitoria ternatea L. American Journal of Plant Sciences 4: 2138-2147.

Nath AJ, Das AK (2010) Gregarious flowering of a long-lived tropical semelparous bamboo Schizostachyum dullooa in Assam. Current Science 99:154-155.

Nath S, Yumnam P, Deb B (2016) Allelopathic effect of lemon plant parts on the seedling germination and growth of lettuce and cabbage. International Journal of Plant Biology and Research 4:1054.

Nega F, Gudeta TB (2019) Allelopathic effect of Eucalyptus globules Labill.On seed germination and seedling growth of highland teff (Eragrostis tef (Zuccagni) Trotter) and barley (Hordum vulgare L.). Journal of Experimental Agriculture International 30: 1-12.
Partey ST, Sarfo DA, Frith O, Kwaku M, Thevathasan NV (2017) Potential of bamboo-based agroforestry for sustainable development in Sub-Saharan Africa: a review. Agricultural Research 6: 22-32.

RafigulHoque ATM, Ahmed R, Uddin MB, Hossain MK (2003) Allelopathy effect of different concentration of water extracts of Acacia auriculiformis leaf on some initial growth parameters of five common agriculture crops. Journal of Agronomy 2: 92-100.

Regila S, Vijayakumar N (2011) Allelopathic effect of Jatropha curcas on selected intercropping plants (green chilli and sesame). Journal of Phytology 3: 01-03.

Saboya P, Borghetti F (2012) Germination, initial growth, and biomass allocation in three native Cerrado species. Brazilian Journal of Botany 35: 129-135.

Salama HM, Al Rabiah HK (2015) Physiological effects of allelopathic activity of Citrullus colocynthis on Vicia faba and Hordeum vulgare. European Journal of Biological Research 5:25-35.

Sisodia S, Siddiqui MB (2008) Allelopathic effect of Lantana camara on Bidenspilosa. VEGETOS 20:29-32.

Sisodia S, Siddiqui MB (2010) Allelopathic effect by aqueous extracts of different parts of Croton bonplandianumBaill. on some crop and weed plants. Journal of Agricultural Extension and Rural Development 2: 022-028.

Sobola OO, Amadi DC, Jamala GY (2015) The role of agroforestry in environmental sustainability. IOSR Journal of Agriculture and Veterinary Science 8: 20-25.

Stachon WJ, Zimdahl RL (1980) Allelopathy activity of Canada thistle Cirsium arvense in Colorado. Weed Science 28:83-86.

Surendra MP, Pota KB (1978) Theallelopathic potentials from root exudates from ages of Celosia argenta Linn. Natural Academy Science Letters 1: 56-58.

Suseelamma M, VenkataRaju RR (1994) Effect of Digera muricata (L.) Mart. extracts on the germination and seedling growth of groundnut. Allelopathy Journal 1: 53-57.

Thakur NS, Dinesh K, Gunaga RP, Susheel S (2017) Allelopathic propensity of the aqueous leaf extracts and leaf litter of Melia dubia Cav. on pulse crops. Journal of Experimental Biology and Agriculture Sciences 5: 644-655.

Wu AP, Li ZL, He FF, Wang YH, Dong M (2015) Screening allelochemical-resistant species of the alien invasive Mikania micrantha for restoration in South China. Plos One 10: e013296. 